\section{Antiestrogenic Action of Atrazine and its Major Metabolites in Vitro}

\author{
Seung Min Oh, Sang Hee Shim, \\ and Kyu Hyuck Chung*
}

College of Pharmacy, Sungkyunkwan University, 300, Chunchun-dong, Jangan-Ku, Suwon, Kyunggi-do 440-746, Korea

(Received September 23, 2002; Accepted November 5, 2002)

Atrazine (2-chloro-4-ethylamino-6-isopropylamino-schlorotriazine), one of the most widely used herbicides, is classified as a possible human carcinogen by the US Environmental Protection Agency and is a known endocrine disruptor. Recent research has indicated that the estrogenic and antiestrogenic effects elicited by this chemical are not mediated by the estrogen receptor. In this study, we also observed that not only atrazine but also its metabolites did not affect basal or $17 \beta$-estradiol induced MCF7-BUS cell proliferation. Therefore, to explain the apparent endocrine disrupting effects of atrazine in vivo, an estrogen-independent mechanism and its metabolites were studied. We examined the alteration in aromatase (CYP19) activity in human choriocarcinoma JEG-3 cells by atrazine and its major metabolites (hydroxyatrazine, diaminochlorotriazine), the conversion of estradiol to hydroxylated metabolites by these compounds associated with cytochrome P4501A. The common metabolite of atrazine, diaminochlorotriazine inhibited the aromatase activity responsible for estrogen synthesis in JEG-3 cells. Atrazine and its metabolites induced 7ethoxyresorufin- $O$-deethylase activity and catalyzed estrogen metabolism in MCF-7 cells. These results suggest that the antiestrogenic effects of atrazine may relate to a decrement in estrogen levels caused by aromatase inhibition and estrogen metabolism stimulation by atrazine and its metabolites.

Key words — atrazine, metabolites, antiestrogenicity, E-screen assay, aromatase activity, 7-ethoxyresorufin- $O$ deethylase activity

\footnotetext{
*To whom correspondence should be addressed: College of Pharmacy, Sungkyunkwan University, 300, Chunchun-dong, Jangan-Ku, Suwon, Kyunggi-do 440-746, Korea. Tel.: +82-31290-7714; Fax: +82-31-292-8800; E-mail: khchung@skku.ac.kr
}

\section{INTRODUCTION}

Atrazine(2-chloro-4-ethylamino-6-isopropylaminos-triazine) has been a widely used herbicide for the control of weeds in the cultivation of corn and sugarcane, among other crops, for many years. Atrazine is classified as a possible human carcinogen by the US Environmental Protection Agency, and is a known endocrine disruptor. However, the exact mechanisms of the mammalian toxicity of this herbicide are unknown.

Recent studies have investigated the short- and long-term effects of atrazine on mammary tumor formation, and various uterine responses in female rats. ${ }^{1-4)}$ Those studies found that atrazine might possess estrogenic and/or antiestrogenic activities in vivo. Dietary administration of atrazine at the maximum tolerated dose to female Sprague-Dawley rats caused lengthening of the estrous cycle and increased the number of days in estrus or under the influence of exposure to estrogen. ${ }^{1)}$ However, atrazine inhibited $17 \beta$-estradiol $\left(\mathrm{E}_{2}\right)$-induced responses following oral administration at extremely high doses. There is also evidence suggesting that atrazine decreases rat uterinary estrogen receptor (ER) binding and uterine wet weights. Moreover, rats that were treated with $E_{2}$ plus atrazine experienced a decrease in $E_{2-}$ induced progesterone receptor (PR) binding and DNA synthesis. ${ }^{3,4)}$ Connor and coworkers reported that atrazine did not affect basal or $\mathrm{E}_{2}$-induced responses in vitro using MCF-7 human breast cancer cell lines. ${ }^{5)}$ In addition, the estrogen-dependent recombinant PL3 yeast strain was not capable of growth on minimal media supplemented with atrazine in place of $\mathrm{E}_{2}$. Collectively, these results indicate that the reported estrogenic and antiestrogenic effects elicited by this compound are not mediated by the ER.

Therefore it is necessary to study the different mechanisms of action of atrazine by which it alters the endocrine system and the effects of its metabolites. Steroidogenesis and estradiol metabolism are potential mechanisms of the ER-independent response. Aromatase cytochrome P450 (CYP) enzyme activity catalyzes the conversion of androgens to estrogens in a number of human tissues, such as the placenta, gonads, adipose tissue, skin, and brain. ${ }^{6}$ ) The CYP19 steroids androstenedione, testosterone and $16 \alpha$-hydroxyandrostenedione are converted to estrone, $\mathrm{E}_{2}$, and estriol by aromatase, the product of the CYP19 gene, and the flavoprotein NADPH-cytochrome (NADPH-CYP) reductase. Excessive or 
inappropriate aromatase expression in various tissues is associated with abnormal concentrations of circulating and/or local estrogen.

CYPs play a central role in the oxidative metabolism of many endogenous and exogenous compounds. ${ }^{7)}$ Estrogen also undergoes extensive metabolism via the action of various forms of CYP450. Oxidation of estrogens can lead to deactivation and elimination, or alternatively, may result in the production of, metabolites that have altered hormonal properties. ${ }^{8,9)}$ For example, the metabolism of $\mathrm{E}_{2}$ to 2-hydroxyestrone (2-OHE1) means a changes to weak estrogen and, more probably, an antiestrogen in a variety of models. ${ }^{10)}$ 2-Hydroxylation of estradiol or estrone to a catechol is a major metabolic pathway in the liver, ${ }^{11-13)}$ and cytochrome P450 1A2 are major enzymes for estrogen 2-hydroxylation. ${ }^{13-15}$ Radiometric studies by Fishman et al. have shown that in normal subjects 2-hydroxylation accounts for between $30 \%$ and $40 \%$ of estradiol metabolism. ${ }^{16)}$

In this study, to explore potential mechanisms of the apparent in vivo estrogenic and antiestrogenic activities of atrazine, the proliferation of MCF7-BUS cells, alteration of aromatase, and hormone metabolism by atrazine and its major metabolites were examined. The E-screen assay, using a more sensitive cell line (MCF7-BUS) than in a previous report, ${ }^{5)}$ was performed to investigate the estrogenic/ antiestrogenic effects of atrazine and its metabolites. Aromatase activity and 7-ethoxyresorufin- $O$ deethylase (EROD) activity were measured associated with CYP450, which catalyzes the biosynthesis and metabolism of estrogen.

\section{MATERIALS AND METHODS}

Chemicals _ Atrazine and its metabolites were dissolved in DMSO as 1000-fold stock solution and $1 \mu \mathrm{l}$ of this solution was added to the medium for treatment in 24-well plates.

\section{Stripping Sex Steroids from Serum with Char-} coal-Dextran Treatment - Charcoal was washed twice with cold sterile water immediately before use. A 5\% charcoal-0.5\% dextran (CD) T70 suspension was prepared. CD suspension as centrifuged at $2000 \times g$ for $10 \mathrm{~min}$. Supernatants were aspirated and serum aliquots were mixed with the charcoal pellets. This charcoal-serum mixture was maintained in suspension by rolling at 6 cycles/min at $37^{\circ} \mathrm{C}$ for $1 \mathrm{hr}$. This suspension was centrifuged at $2000 \times g$ for $20 \mathrm{~min}$. The supernatant was filtered through a $0.45 \mu \mathrm{m}$ and $0.20 \mu \mathrm{m}$ bottle top filter (Nunc). The sex steroid-free CD serum (CDFBS) was stored at $-20^{\circ} \mathrm{C}$ until needed.

E-Screen Assay — Estrogen-sensitive human breast cancer MCF7-BUS cells were obtained from Dr. Soto (Tufts University, Boston, U.S.A.). Cells were grown in Dulbecco's modified Eagle's medium (DMEM) supplemented with 5\% fetal bovine serum (FBS), penicillin (10000 units/ml), and streptomy$\operatorname{cin}(10000 \mu \mathrm{g} / \mathrm{ml})$ at $37^{\circ} \mathrm{C}$ in an atmosphere of $5 \%$ $\mathrm{CO}_{2} / 95 \%$ air under saturating humidity. This assay is a widely used model of estrogen-dependent cell proliferation using human breast cancer cells. MCF7BUS cells were trypsinized and seeded into 24-well plates at initial concentrations of 10000 cells per well. Cells were attached for $24 \mathrm{hr}$, and the seeding medium (5\% FBS in DMEM) was replaced with the experimental medium (10\% CDFBS supplemented with phenol red-free DMEM). Test compounds were added to this medium at a range of concentrations. The assay was terminated after $144 \mathrm{hr}$ by removing media from the well, fixing the cells, and staining with sulforhodamine-B (SRB). Bound dye was dissolved in $10 \mathrm{mM}$ Tris base (pH 10.5). Finally, aliquots were transferred to a 96 -well plate to be read in an ELISA reader at $490 \mathrm{~nm} .{ }^{17)}$

Aromatase Activity Assay — Human choriocarcinoma JEG-3 cells were purchased from the American Type Culture Collection (ATCC). The cells were maintained in culture medium consisting of DMEM supplemented with penicillin (10000 units $/ \mathrm{ml})$ and streptomycin $(10000 \mu \mathrm{g} / \mathrm{ml})$ at $37^{\circ} \mathrm{C}$ in an atmosphere of $5 \% \mathrm{CO}_{2} / 95 \%$ air under saturating humidity. JEG-3 cells were trypsinized and seeded in 24well culture plates at initial concentrations of 50000 cells per well. Incubation media $(0.1 \% \mathrm{v} / \mathrm{v}$ DMSO in culture medium, phenol red-free DMEM) were prepared just prior to incubation. After 2 days (when the wells were approximately $80 \%$ confluent) culture media were replaced by $1 \mathrm{ml}$ of incubation media and incubated for $18 \mathrm{hr}$ at $37^{\circ} \mathrm{C}$ in an atmosphere of $5 \% \mathrm{CO}_{2} / 95 \%$ air. Every incubation was performed in quadruplicate for the aromatase assay. The cells were washed twice with $1 \mathrm{ml}$ of serumfree DMEM and assayed for aromatase activity. The effects of atrazine and its metabolites were investigated in cells incubated in the absence of $10 \%$ FBS, since serum could affect the regulation of aromatase activity. After aromatase activities were determined, the cells were lysed with $0.1 \mathrm{M} \mathrm{NaOH} 1 \mathrm{ml}$ and the protein content of the wells was measured using the method of Lowry et al. ${ }^{18)}$ with bovine serum albu- 
$\min (\mathrm{BSA})$ as the standard.

$\left[1 \beta{ }^{3} \mathrm{H}\right]$ Androstenedione (lot no. 3329278; specific activity $1054.5000 \mathrm{GBq} / \mathrm{mmol}$ ) was purchased from Dupont (NEN Research Products). Aromatase activity was determined using the method described by Lephart and Simpson ${ }^{19)}$ by measuring the amount of ${ }^{3} \mathrm{H}_{2} \mathrm{O}$ formed during aromatization of $[1 \beta$ $\left.{ }^{3} \mathrm{H}\right]$ androstenedione. Just prior to measurement, $[1 \beta$ $\left.{ }^{3} \mathrm{H}\right]$ androstenedione was dissolved in serum-free culture medium at a concentration of $54 \mathrm{nM}$, which is the approximate $\mathrm{Km}$ value for the aromatization of androstenedione in JEG-3 cell, ${ }^{20)}$ and $0.25 \mathrm{ml}$ of this solution was added to each well. Medium was added to wells without cells to determine blank values. After an incubation of $1 \mathrm{hr}$ at $37^{\circ} \mathrm{C}$ in an atmosphere of $5 \% \mathrm{CO}_{2} / 95 \%$ air under saturating humidity, the plates were placed on ice and $200 \mu \mathrm{l}$ of the culture medium was withdrawn from each well. The medium was extracted with chloroform $500 \mu \mathrm{l}$, vortexed, and centrifuged for $2 \mathrm{~min}$ at $9000 \times \mathrm{g}$. A $100 \mu \mathrm{l}$ aliquot of the aqueous phase was mixed with $100 \mu \mathrm{l}$ of $5 \% \mathrm{w} / \mathrm{v}$ charcoal $0.5 \% \mathrm{w} / \mathrm{v}$ dextran T-70 suspension, vortexed for $30 \mathrm{sec}$ and incubated for $10 \mathrm{~min}$. After centrifugation for $5 \mathrm{~min}$ at $9000 \times \mathrm{g}$, an aliquot of $150 \mu \mathrm{l}$ was mixed with a 4-ml cocktail and assayed for radioactivity in a liquid scintillation counter. To determine the aromatase activity, corrections were made for background, radioactivity of blanks, dilution, recovery of ${ }^{3} \mathrm{H}_{2} \mathrm{O}$, and ${ }^{3} \mathrm{H}$ distribution of $\left[1 \beta^{3} \mathrm{H}\right]$ androstenedione.

EROD Assay — The MCF7-BUS cells were trypsinized and seeded in 24-well culture plates at initial concentrations of 50000 cells per well. After 2 days (when wells were approximately $80 \%$ confluent), media were exchanged with phenol redfree DMEM. Chemicals were added to the medium for treatments that were done in 24-well plates and lasted $48 \mathrm{hr}$. EROD enzyme activity was measured using a fluorimetric assay. Every experiment was performed in quadruplicate for EROD enzymatic assay. EROD enzymatic assay was measured as described by Burke and Mayer, ${ }^{21)}$ with some modifications. Monolayers were washed twice with PBS. Just prior to the EROD assay, dicumarol $1 \mu \mathrm{M}$ and ethoxyresorufin solution $1 \mu \mathrm{M}$ in DMSO were dissolved in serum-free culture medium at final concentrations of 5 and $4 \mu \mathrm{M}$, respectively. One milliliter of this incubation medium was added to each well. The incubation was performed for $30 \mathrm{~min}$ at $37^{\circ} \mathrm{C}$ in an atmosphere of $5 \%$ carbon dioxide, and then the media were withdrawn from the wells. The fluorescence was measured at 530/588 $\mathrm{nm}$ excitation/ emission wavelengths. The amount of resorufin formed was calculated from a calibration curve for resorufin. After EROD activities were determined, the cells were lysed with $0.1 \mathrm{M} \mathrm{NaOH} 1 \mathrm{ml}$ and the protein content of the wells was measured using the method of Lowry et al. ${ }^{18)}$ with BSA as the standard. Data Analysis — Each data point represents the mean \pm S.D. of three independent experiments where three independent wells were used for one experiment. Student's $t$-test was used with the SigmaPlot program, and differences were accepted as statistically significant when $p<0.05$.

\section{RESULTS AND DISCUSSION}

There may be numerous mechanisms by which atrazine can potentially cause endocrine alterations. Atrazine possess estrogenic/antiestrogenic activities in vivo. ${ }^{3,4)}$ The weak hormone-related activity of atrazine could play an important role in the observed disruptive actions of atrazine correlated to mammary tumors. ${ }^{1,2,22)}$ However, the apparent mechanisms of estrogenic/antiestrogenic activities of atrazine are still unknown. In particular, reports on the effects of the metabolites of atrazine responsible for endocrine disruption are insufficient.

It has been reported that the major animal metabolites arise from $N$-dealkylation. The metabolism of atrazine appears to be rather complicated, although 2-chloro-4-ethylamino-6-amino-striazine (deethylatrazine), 2-chloro-4-amino-6isopropylamino-s-triazine (deisopropylatrazine), 2chloro-4-amino-6-amino-s-triazine (diaminochlorotriazine [DACT]), and 2-hydroxy-4-ethylamino-6isopropylamino-s-triazine (hydroxy-atrazine [HAT]) have been identified as degradation products of atrazine in animals (Fig. 1). ${ }^{23-27)}$

We examined whether atrazine and its major metabolites had estrogenic and/or antiestrogenic activities through cell proliferation using ER-positive MCF7-BUS human breast cancer cell. In the cell proliferation test with MCF-7 cells, the so-called E-screen assay, atrazine and its metabolites did not affect cell proliferation. As shown in Table 1, the relative proliferative effect of the three test compounds was less then 8 , meaning that atrazine and its metabolites (HAT and DACT) are not estrogen agonists. In addition, these compounds at concentrations of $10^{-5}-10^{-11} \mathrm{M}$ did not block the growthenhancing capability of $\mathrm{E}_{2}$ and thus evidently exert their endocrine-disrupting effect by another mecha- 
<smiles>CC(C)Nc1nc(O)nc(N(C)C)n1</smiles>

(II)

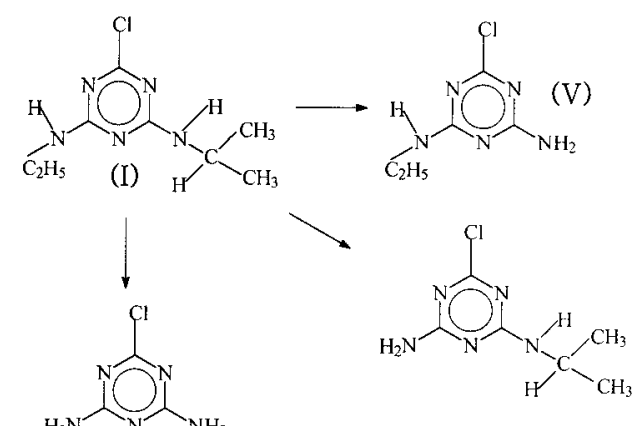

(III)

Fig. 1. Chemical Structures of Atrazine and its Metabolites

(I) Atrazine; (II) HAT; (III) DACT (common metabolites); (IV) deethylatrazine; (V) deisopropylatrazine.

Table 1. Estrogenicity of Atrazine and its Metabolites Expressed as Relative Proliferative Effect (RPE, \%) by the E-Screen Assay

\begin{tabular}{cccc}
\hline \hline $\begin{array}{c}\text { Compound } \\
\text { Concentration }(\mathrm{M})\end{array}$ & Atrazine & Diaminochlorotriazine & Hydroxyatrazine \\
\hline $10^{-12}$ & 1.2 & 3.4 & 0.1 \\
$10^{-10}$ & 1.9 & 2.9 & 2.8 \\
$10^{-8}$ & 1.2 & 6.0 & 1.1 \\
$10^{-6}$ & 1.0 & 4.8 & $\left.5.0^{a}\right)$ \\
$10^{-5}$ & 2.9 & 8.0 & \\
\hline
\end{tabular}

a) RPE at $3 \times 10^{-7} \mathrm{M}$ hydroxyatrazine (maximum soluble dose tested). Incubation with DMSO alone was performed as a control and the final concentration of DMSO in the medium did not exceeded $0.1 \%$ (control RPE $=0 \%$ ). The proliferative effects of compounds relative to $\mathrm{E}_{2}\left(10^{-10} \mathrm{M} \mathrm{RPE}=100 \%\right.$, positive control $)$ are represented as RPE. RPE is calculated as $100 \times$ proliferative effect- 1 (PE-1) of the test compound/(PE-1) of $\mathrm{E}_{2}$.

nism different from the ER response (Fig. 2).

To explain the previously reported disruptive actions of atrazine and its major metabolites, we investigated that alteration of the CYP450 enzyme associated with hormone synthesis and degradation. Aromatase CYP19 enzyme activity catalyzes the conversion of androgens to estrogens in a number of human tissues. As shown in Fig. 3, the known irreversible aromatase inhibitor ${ }^{28-31)}$ 4hydroxyandrostenedione inhibited aromatase activity in JEG-3 cells in a dose-dependent manner with $\mathrm{IC}_{50}$ values of $10^{-8} \mathrm{M}$. However, no significant differences were observed between the treatment with atrazine and HAT $\left(10^{-8}\right)$. In contrast, DACT $\left(10^{-8}-10^{-5} \mathrm{M}\right)$ caused a dose-dependent decrease in aromatase activity (Fig. 3).

We also measured EROD activity associated with CYP4501A in MCF-7 cells, which catalyzed the $\mathrm{E}_{2}$ metabolism to weak estrogen, 2hydroxyestrone (2-OHE1). ${ }^{10-12,32,33)}$ As shown in Fig. 4, the induction of EROD activity by atrazine

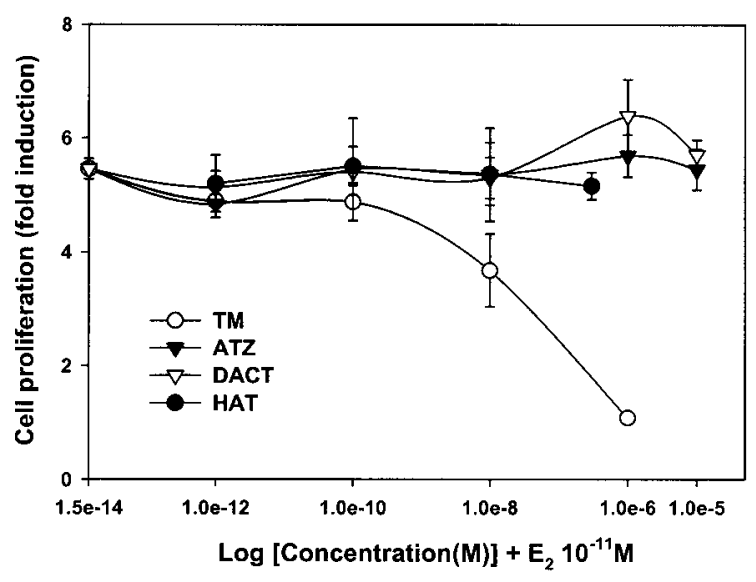

Fig. 2. Effects of Atrazine and its Metabolites on the Cell Proliferation in MCF7-BUS Cells

Cells were incubated in DMEM supplemented with $10 \%$ CDFBS with E2 $\left(10^{-11} \mathrm{M}\right)$ or a combination of $\mathrm{E}_{2}$ and Tamoxifen, atrazine, DACT, or HAT for $144 \mathrm{hr}$. The final concentration of vehicle in medium did not exceed $0.1 \%$. After incubation for $144 \mathrm{hr}$, Sulforhodamine assay was conducted to measure cell proliferation as described in Methods. Results are expressed as means and S.D. of four separate experiments for each data point. ATZ, atrazine; DACT, diaminochlorotriazine; HAT, hydroxyatrazine. 


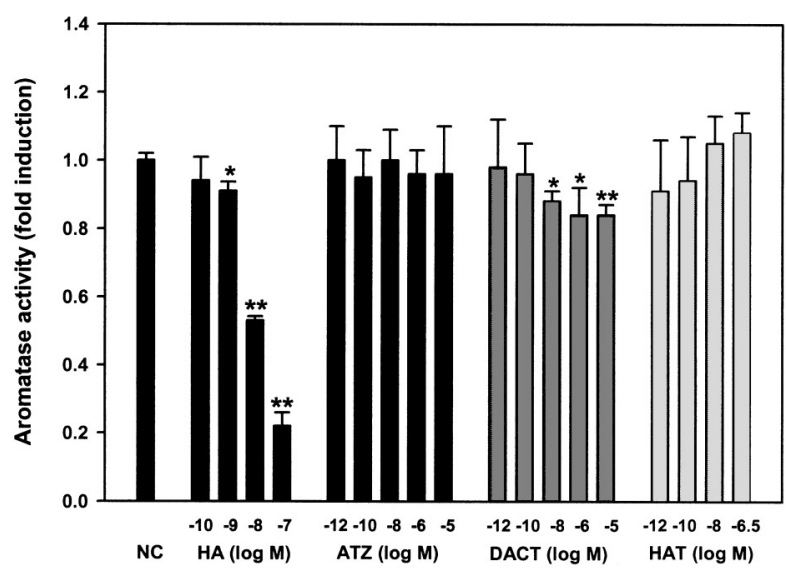

Fig. 3. Effects of Atrazine and its Metabolites on the Aromatase Activity in JEG-3 Cells

Cells were incubated in DMEM supplemented with 3\% CDFBS with atrazine, DACT, or HAT for $18 \mathrm{hr}$. DMSO was used as a negative control (NC), and 4-hydroxyandrostenedione (HA) was used as a positive control. The final concentration of DMSO in medium did not exceed $0.1 \%$. After incubation for $18 \mathrm{hr}$, cells were treated with $54 \mathrm{nM}$ [1 $\beta-$ $\left.{ }^{3} \mathrm{H}\right]$ androstenedione for $1 \mathrm{hr}$. Aromatase activity was determined using the tritium release assay. ${ }^{3} \mathrm{H}_{2} \mathrm{O}$ formed by aromatase activity was measured as described in Methods. Aromatase activity is expressed as the amount of tritiated water (pmol) formed by aromatase activity. Comparisons were made using Student's $t$-test. Values significantly different from NC $(0.1 \%$ DMSO $) * p<0.05, * * p<0.01$. ATZ, atrazine; DACT, diaminochlorotriazine; HAT, hydroxyatrazine.

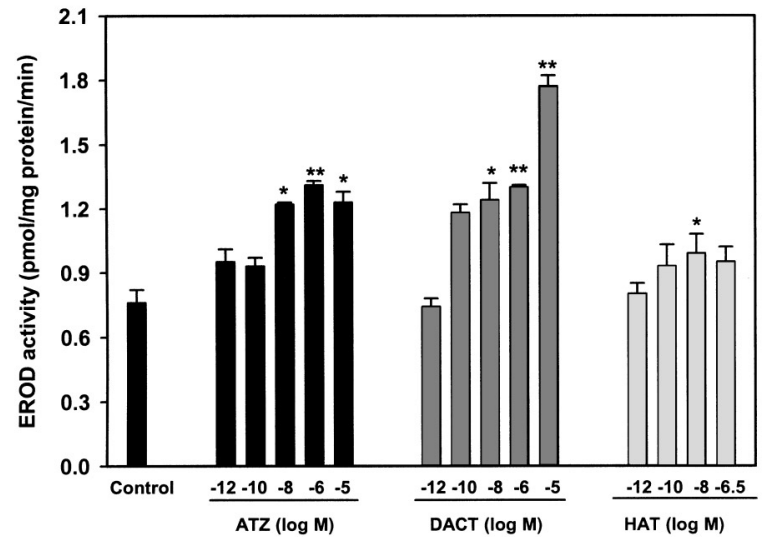

Fig. 4. Effects of Atrazine and its Metabolites on the EROD Activity in MCF7-BUS Cells

Cells were incubated in DMEM supplemented with 5\% FBS with atrazine, DACT, or HAT for $48 \mathrm{hr}$. DMSO was used as a negative control (Control). The final concentration of DMSO in medium did not exceed $0.1 \%$. After incubation for $48 \mathrm{hr}$, EROD activity was determined as described in Methods. Results are expressed as means and S.D. of three separate experiments for each data point. Comparisons were made using Student's $t$-tests. Values significantly different from control $(0.1 \%$ DMSO) $* p<0.05, * * p<0.01$. ATZ, atrazine; DACT, diaminochlorotriazine; HAT, hydroxyatrazine.

and DACT was observed in a concentration dependent manner $\left(10^{-8}-10^{-5} \mathrm{M}\right)$. However, HAT did not induce greater CYP 1A activity in comparison with atrazine or DACT. These results may be related to the antiestrogenic effects of atrazine in vivo.

In conclusion, we have corroborated evidence that atrazine and its metabolites do not exhibit agonist and/or antagonist activities through a direct estrogen response. Our present results suggest that possible mechanism of the antiestrogenicity of atrazine could be via decrements in estrogen levels due to inhibition of aromatase activity and stimulation of $E_{2}$ metabolism. Further investigations are necessary to clarify the mechanism responsible for these effects.

Acknowledgements This study was supported by Grant No. R07-2000-00328 from the Basic Research Program of the Korea Science and Engineering Foundation.

\section{REFERENCES}

1) Wetzel, L. T., Luempert, L. G., Breckenridge, C. B., Trisdel, M. O., Stevens, J. T., Thakur, A. J., Extrom, P. C. and Elderidge, J. C. (1994) Chronic effects of atrazine on estrus and mammary formation in female Sprague-Dawley and Fischer 344 rats. J. Toxicol. Environ. Health, 43, 169-182.

2) Stevens, J. T., Breckenridge, C. B., Wetzel, L. T., Gillis, J. H., Luempert, L. G., III and Elderidge, J. C. (1994) Hypothesis for mammary tumorigenesis in Sprague-Dawley rats exposed to certain triazine herbicides. J. Toxicol. Environ. Health, 43, 139-153.

3) Tennant, M. K., Hill, D. S., Elderidge, J. C., Wetzel, L. T., Breckenridge, C. B. and Steven, J. T. (1994a) Possible antiestrogenic properties of chloro- $S$ triazines in rat uterus. J. Toxicol. Environ. Health, 43, 183-196.

4) Tennant, M. K., Hill, D. S., Elderidge, J. C., Wetzel, L. T., Breckenridge, C. B. and Steven, J. T. (1994b) Chloro-S-triazine antagonism of estrogen action: Limited interaction with estrogen receptor binding. J. Toxicol. Environ. Health, 43, 197-211.

5) Connor, K., Howell, J., Chen, I., Liu, H., Berhane, K., Sciarretta, C., Safe, S. and Zacharewski, T. (1996) Failure of chloro-S-triazine-derived compounds to induce estrogen receptor-mediated responses in vivo and in vitro. Fundam. Appl. Toxicol., 30, 93-101.

6) Simpson, E. R., Mahendroo, M. S., Means, G. D., Kilgore, M. W., Hinshelwood, M. M., GrahamLorence, S., Amarneh, B., Ito, Y., Fischer, C. R., Michael, M. D., Mendelson, C. R. and Bulun, S. E. 
(1994) Aromatase cytochrome P450, the enzyme responsible for estrogen biosynthesis. Endocr. Rev., 15, 342-355.

7) Gonzalez, F. J. (1988) The molecular biology of cytochrome P450s. Pharmacol. Rev., 60, 1107-1166.

8) Ryan, K. J. (1958) Conversion of androstenedione to estrone by placental microsomes. Biochem. Biophysic. Acta., 27, 658-662.

9) Martucci, C. P. and Fishman, J. (1993) P450 enzymes of estrogen metabolism. Pharmacol. Ther., 57, 237257.

10) Gordon, J., Cantrall, W. P., Albers, H. J., Mauer, S. and Stolar, S. M. (1964) Steroids and lipid metabolism: The hypocholesteremic effect of estrogen metabolites. Steroids, 4, 267-291.

11) Suchar, L. A., Chang, R. L., Rosen, R. T., Lech, J. and Conney, A. H. (1995) High performance liquid chromatography separation of hydroxylated estrdiol metabolites: formation of estradiol metabolites by liver microsomes from male and female rats. $J$. Pharmacol. Exp. Ther., 272, 197-206.

12) Dannan, G. A., Porubek, D. J., Netson, S. D., Waxman, D. J. and Guengerich, F. P. (1986) $17 \beta$ Estradiol 2- and 4-hydroxylation catalyzed by rat hepatic cytochrome P450: roles of individual forms, inductive effects, developmental patterns, and alterations by gonadectomy and hormone replacement. Endocrinology, 118, 1952-1960.

13) Kerlan, V., Dreano, Y., Bercovici, J. P., Beaune, P. H., Floch, H. H. and Berthou, F. (1992) Nature of cytochrome $\mathrm{P} 450$ involved in the 2-/4-hydroxylation of estradiol in human liver microsomes. Biochem. Pharmacol., 44, 1745-1756.

14) Ball, S. E., Forrester, L. M., Wolf, C. R. and Back, D. J. (1990) Differences in the cytochrome P450 isoenzymes involved in the 2-hydroxylation of oestradiol and $17 \alpha$-ethylestradiol. Biochem. J., 267, 221-226.

15) Shou, M., Korzekwa, K. R., Brooks, E. N., Krausz, K. W., Gonzalez, F. J. and Gelboin, H. V. (1997) Role of human hepatic cytochrome P450 1A2 and $3 \mathrm{~A} 4$ in the metabolic activation of estrone. Carcinogenesis, 18, 207-214.

16) Fishman, J., Bradlow, H. L., Schneider, J., Anderson, K. E. and Kappas, A. (1980) Radiometric analysis of biological oxidation in man: sex differences in estradiol metabolism. Proc. Natl. Acad. Sci. U.S.A., 77, 4957-4960.

17) Villalobos, M., Olea, N., Brotons, J. A., OleaSerrano, M. F., Almodovar, J. M. and Pedraza, V. (1995) The E-SCREEN assay: a comparison of different MCF7 cell stocks. Environ. Health. Perspect., 103, 844-850.

18) Lowry, O. H., Rosebrough, N. J. Farr, A. L. and Randall, R. J. (1951) Protein measurement with the folin phenol reagent. J. Biol. Chem., 193, 265-275.

19) Lephart, E. D. and Simpson, E. R. (1991) Assay of aromatase activity, In Methods in Enzymology, Volume 206, Enzyme Assays (Waterman, M. R. and Johnson, E. F., Eds.), Academic Press, New York, pp. 478-483

20) Krekels, M. D. W. G., Wouters, W., De Coster, R., Van Ginckel, R., Leonaers, A. and Jassen, P. A. J. (1991) Aromatase in the human choriocarcinoma JEG-3, inhibition by R76713 in cultured cells and in tumors grown in nude mice. J. Steroid Biochem. Mol. Biol., 38, 415-422.

21) Burke, M. D. and Mayer, R. T. (1974) Ethoxyresorufin, direct fluorimetric assay of a microsomal dealkylation which is preferentially inducible by 3-methylcholanthrene. Drug Metab. Dispos., 2, 583-588.

22) McDougal, A. and Safe, S. (1998) Induction of $16 \alpha-$ /2-hydroxyestrone metabolite ratios in MCF-7 cells by pesticides, carcinogens, and antiestrogens does not predict mammary carcinogens. Environ. Health. Pperspect., 106, 203-206.

23) Chung, K. H., Ro, K. S. and Roy, D. (1996) Fate and enhancement of atrazine biotranformation in anaerobic wetland sediment. Water Res., 2, 341-346.

24) Winkelmann, D. A. and Klaine, S. J. (1991) Degradation and bound residue formation of atrazine. Environ. Toxicol. Chem., 10, 335-345

25) Kaufmann, D. D. and Kearney, P. C. (1970) Microbial degradation of triazine herbicides. Residue Rev., 32, 235-265.

26) Bakke, J. E., Larson, J. D. and Price, C. E. (1972) Metabolism of atrazine and 2-hydroxyatrazine by the rat. J. Agric. Food Chem., 20, 602-607.

27) Adams, N. H., Levi, P. E. and Hodgson, E. (1990) In vitro studies of the metabolism of atrazine, simazine and terbutyrn in several vertebrate species. J. Agric. Food Chem., 38, 1411-1417.

28) Brodie, A. (1991) Aromatase and its inhibitors an overview. J. Steroid Biochem. Mol. Biol., 40, 255261.

29) Kitawaki, J., Kim, T., Kanno, H., Noguchi, T., Yamamoto, T. and Okada, H. (1993) Growth suppression of MCF-7 human breast cancer cells by aromatase inhibitors: a new system for aromatase inhibitor screening. J. Steroid Biochem. Mol. Biol., 44, 667-670.

30) Kitawaki, J., Fukuoka, M., Yamamoto, T., Honjo, H. and Okada, H. (1992) Contribution of aromatase to the deoxyribonucleic acid synthesis of MCF-7 human breast cancer cells and its suppression by aroamatase inhibitors. J. Steroid Biochem. Mol. Biol., 42, 267-277.

31) Cole, P. A. and Robinson, C. H. (1990) Mechanism and inhibition of cytochrome $\mathrm{P}-450$ aromatase. $J$. 
Med. Chem., 33, 2933-2942.

32) Bradlow, H. L., Telang, N. T., Sepkovic, D. W. and Osborne, M. P. (1996) 2-Hydroxyestrone: the 'good' estrogen. J. Endocrinol., 150, s259-s265.
33) Schneider, J., Huh, M. M., Bradlow, H. L. and Fishman, J. (1984) Antiestrogenic action of 2hydroxyestrone on MCF-7 human breast cancer cells. J. Biol. Chem., 259, 4840-4845. 